\title{
EFEKTIFITAS SISTEM TANAM JAJAR LEGOWO 2:1 DENGAN SISTEM TEGEL TERHADAP PRODUKTIVITAS PADI SAWAH DI SUBAK BABAKAN CANGI, DESA BATUAN KALER, KECAMATAN SUKAWATI, KABUPATEN GIANYAR
}

\author{
I Nengah Surata Adnyana \\ Program Studi Agribisnis, Fakultas Pertanian, Universitas Dwijendra, Denpasar \\ E-mail : surataadnyana@gmail.com
}

\begin{abstract}
Abstrak
Komoditi tanaman pangan seperti beras merupakan kebutuhan pokok bagi sebagian besar penduduk Negara Indonesia sehari-hari, sehingga keberadaannya perlu mendapatkan perhatian lebih didalam melakukan proses usahatani berupa penerapan teknologi budidaya yang baik dan benar. Salah satu teknologi yang selama ini dikembangkan adalah sistem penanaman jajar legowo 2:1. Tujuan penelitian ini adalah (1) Mengetahui pertumbuhan dan tingkat efektivitas sistem tanam jajar legowo 2:1 terhadap produktivitas hasil tanamam padi. (2) Mengetahui kendala didalam pelaksanaan penerapan sistem tanam jajar legowo 2:1 yang ada di Subak Babakan Cangi, Kecamatan Sukawati, Kabupaten Gianyar.

Populasi dalam penelitian ini berjumlah 60 orang petani dan jumlah sampel yang diambil sebanyak 27 orang. Pengambilan sampel secara "sensus" dan secara "simple random sampling". Pengambilan sampel secara sensus adalah petani yang menerapkan sistem tanam jajar legowo 2:1 (jarak tanam 25 X 12,5 X 50 $\mathrm{cm})$ sebanyak 12 orang petani. Sedangkan pengambilan sampel secara "simple random sampling" dilakukan pada petani yang menanam sistem tegel $(25$ X $25 \mathrm{~cm})$ pada musim tanam juni 2020 sebanyak 15 orang yang diambil dari $25 \%$ dari jumlah populasi yang ada.

Hasil penelitian menunjukan (1) Pertumbuhan tanaman padi seperti tinggi tanaman, jumlah anakan/rumpun, panjang malai, gabah isi/malai, gabah hampa/malai mendapatkan hasil lebih baik daripada sistem tegel, serta produktivitas penanaman sistem jajar legowo 2:1 mendapatkan hasil yang lebih efekktife jika dibandingkan menanam sistem tegel. Dimana sistem jajar legowo 2:1 mendapatkan hasil rata-rata 7.52 ton/ha GKP lebih tinggi sebesar 1,32 ton/ha (atau meningkat sebesar 21,29\%) jika dibandingkan dengan penanaman sistem tegel yang mendapatkan rata-rata hasil 6,20 ton/ha. (2) Permasalahan yang terjadi dilapangan dalam pelaksanaan sistem tanam jajar legowo 2:1 yaitu: mahalnya biaya penanaman, kebanyakan petani penggarap, petani kebanyakan menjual hasil panennya ke penebas.

Saran yang dapat diberikan yaitu: perlu melakukan pengembangan penanaman dengan sistem jajar legowo 2:1 secara luas, peran pemerintah untuk mensosialisasikan, kombinasi penerapan dengan padi hibrida, pemanenan dilakukan secara mandiri, pengembangan kelompok panen dan mengadakan sekolah lapang dengan sistem agribisnis.

Kata kunci : Jajar legowo 2:1, Efektifitas, Produktivitas.
\end{abstract}

\begin{abstract}
A food crop commodity such as rice is a daily basic requirement for the majority of Indonesia's population, so that its existence needs to get more attention in carrying out the farming process in the form of applying good and correct cultivation technology. One of the technologies that has been developed so far is the 2: 1 legowo row planting system. The objectives of this study were (1) to determine the growth and effectiveness of the 2: 1 legowo row system on the productivity of rice planting. (2) Knowing the obstacles in implementing the legowo row planting system 2: 1 in Subak Babakan Cangi, Sukawati District, Gianyar Regency.

The population in this study amounted to 60 farmers and the number of samples taken was 27 people. Sampling was "census" and "simple random sampling". Sampling by census was 12 farmers who applied legowo row planting system (25 X 12.5 X $50 \mathrm{~cm}$ spacing). Meanwhile, the sample collection using "simple random sampling" was carried out on farmers who planted the tile system $(25 \times 25 \mathrm{~cm})$ in the growing season of June 2020 as many as 15 people taken from $25 \%$ of the total population.

The results showed (1) the growth of rice plants such as plant height, number of tillers / clumps, length of panicles, filled grain / panicles, empty grain / panicles got better results than the tile system, and the productivity of planting the legowo row system 2: 1 got better results. more effectife than planting a tile system. Where the legowo row system 2: 1 gets an average yield of 7.52 tonnes / ha, GKP is higher by 1.32 tonnes / ha (or an increase of $21.29 \%$ ) when compared to the tile system planting which gets an average yield of 6.20 ton / ha. (2) The problems that occur in the field in implementing the legowo row 2: 1 planting system are: the high cost of planting, most are cultivators, most of them sell their crops to middleman.
\end{abstract}


Suggestions that can be given are: it is necessary to develop planting with the legowo row system 2: 1 extensively, the role of the government to disseminate it, a combination of application with hybrid rice, harvesting done independently, developing harvest groups and holding field schools with an agribusiness system.

Keywords: Jajar legowo 2: 1, Effectiveness, Productivity.

\section{PENDAhuluan}

Beras merupakan komoditi pangan yang merupakan kebutuhan masyarakat Indonesia sehari-hari, sehingga keberadaannya sangat pital dalam perekonomian suatu bangsa. Berbagai upaya telah dilakukan oleh pemerintah didalam mencapai kedaulatan dan ketahanan pangan beras mulai dari (1) susbsistem penyediaan saranan produksi berupa pemberian subsidi pupuk, subsidi benih, bantuan handtraktor, dll; (2) subsistem usahatani seperti melakukan pengelolaan tanaman terpadu (SL-PTT), sekolah lapang pengendalian hama terpadu (SL-PHT); (3) subsistem pasca panen dan agroindustri yaitu penanganan pasca panen yang baik serta pengolahannya supaya memiliki nillai ekonomis yang lebih tinggi; (4) subsistem pemasaran, melakukan kerjasama dengan pengelola LUEP; dan (5) subsistem jasa penunjang salah satunya mendorong keberadaan penyuluh dilapangan supaya lebih efektif didalam melakukan pendampingan lapangan. Selama ini cara meningkatkan produksi padi dapat dilakukan dengan tiga pendekatan yaitu meningkatkan produktivitas tanaman, menambah areal luas tanam atau panen, dan menambah intensitas tanam. Subsistem usahatani yang selama ini yang terus digalakan dan dikembangkan adalah teknologi budidaya dengan sistem tanam jajar legowo.

Sistem tanam jajar legowo merupakan pola bertanam yang berselang-seling antara dua atau lebih baris tanaman padi dan satu baris kosong. Sistem legowo adalah suatu rekayasa teknologi untuk mendapatkan populasi tanaman lebih dari 160.000 per hektar. Penerapan Jajar Legowo selain meningkatkan populasi pertanaman, juga mampu menambah kelancaran sirkulasi sinar matahari dan udara disekeliling tanaman pingir sehingga tanaman dapat berfotosintesa lebih baik (Badan Litbang Pertanian, 2013). Sistem tanam jajar legowo merupakan rekayasa teknologi untuk mengoptimalkan produktivitas padi melalui pengaturan populasi agar tanaman mendapatkan ruang tumbuh dan sinar matahari yang optimum (Hamdani dan Murtiani, 2014).

Selama ini sistem tanam jajar legowo sudah sering dilakukan pada kelompok tani sehingga perlu dilakukan tingkat efektifitasnya dilapangan. Kinerja suatu program ditentukan oleh tingkat efektivitas dan efisiensi pelaksanaan program dalam mencapai tujuan atau sasaran. Efektifitas merupakan ukuran untuk menggambarkan sejauhmana sasaran dapat dicapai (Atmosoeprapto, 2001). Efektivitas lebih mengarah kepada pencapaian sasaran atau tujuan yang direncanakan. Hasil yang semakin mendekati sasaran berarti derajat efektivitasnya semakin tinggi (Supari, 2002). Menurut Price (dalam Umar, 2005), indikator yang dipakai untuk mengukur efektifitas adalah produktivitas, moral, persesuaian, kemampuan adaptasi dan kemampuan melembaga dimana produktivitas dijadikan sebagai indikator yang paling utama/erat kaitannya dengan efektifitas. Untuk itu perlu dilakukan pengukuran tingkat efektifitas didalam pelaksanaan penanaman sistem tanam jajar legowo. Berdasarkan pada uraian latar belakang diatas, masalah dalam penelitian ini dapat dirumuskan sebagai berikut (1) Bagaimana pertumbuhan serta tingkat efektifitas sistem tanam jajar legowo 2:1 dan sistem tegel terhadap produktivitas hasil tanamam padi yang ada di Subak Babakan Cangi, Kecamatan Sukawati, Kabupaten Gianyar; (2) Bagaimana permasalahan- 
permasalahan didalam didalam pelaksanaan penerapan sistem tanam jajar legowo 2:1 di Subak Babakan Cangi, Kecamatan Sukawati, Kabupaten Gianyar.

\section{METODE}

Penelitian ini diaksanakan di Subak Babakan Cangi, Desa Batuan Kaler, Kecamatan Sukawati, Kabupaten Gianyar, Provinsi Bali. Tempat lokasi ditentuka secara "purposive " yaitu teknik penentuan lokasi secara sengaja berdasarkan dengan pertimbangan-pertimbangan tertentu,seperti memiliki potensi untuk pengembangan produksi padi dan pengairan yang baik. Populasi dalam penelitian ini berjumlah 60 orang petani. Sampel yang diambil berjumlah 27 orang petani. Pengambilan sampel diambil secara sensus untuk petani yang menerapkan penanaman dengan sistem jajar legowo 2:1 sebanyak 12 orang pada bulan juni 2020 dan secara "simple random sampling" untuk petani yang menanam padi dengan sistem tegel pada bulan juni 2020, yaitu sebanyak 15 orang yang diambil dari $25 \%$ dari jumlah populasi, kemudian data dianalisis secara kualitatif dan kuantitatif.

Jenis data yang digunakan adalah data kuantitatif dan data kualitatif. Sumber data yang diguanakan adalah data primer dan data sekunder. Data kualitatif dari hasil kuesioner dilapangan ditransformasikan menjadi angka (skor) sehingga dianalisis menggunakan metode statistik deskriptif. Indikator produktivitas padi diukur menggunakan skala ordinal dengan rentang 1 sampai 5, dengan kategori tidak efektif, kurang efektif, cukup efektif, efektif, dan sangat efektif. Pengumpulan data dilakukan dengan wawancara terstruktur, wawancara mendalam dan observasi. Wawancara (intervew) dilakukan dengan menggunakan kuesioner yang telah dipersiapkan sebelumnya.

\section{HASIL DAN PEMBAHASAN}

Berdasarkan hasil pengamatan dilapangan yang ada di subak babakan cangi, desa Batuan kaler, Kecamatan Sukawati. Perlakuan tanam sistem jajar legowo 2:1 mendapatkan tinggi tanaman rata-rata yang lebih tinggi dibandingkan dengan sistem tegel biasa $(25 \mathrm{~cm} \mathrm{X} 25 \mathrm{~cm})$. Pada umur tanaman 30 HST, 60 HST dan 80 HST sistem tanam jajar legowo 2:1 mendapatkan rata-rata tinggi tanaman 72,21 cm (umur 30 HST), 108,10 cm (umur 60 HST), dan 110,10 cm (umur 80 HST); sedangkan pada sistem tanam tegel (jarak tanam $25 \mathrm{~cm}$ X $25 \mathrm{~cm}$ ) pada umur 30 HST, $60 \mathrm{HST}$ dan 80 Hst, mendapatkan tinggi tanaman berturut-turut 70,11 cm, 105,22 cm dan 108,11 cm.

Rata-rata jumlah anakan yang dicapai antara penanaman sistem jajar legowo 2:1 dengan sistem Tegel terjadi perbedaan. Rata-rata jumlah anakan dengan sistem jajar legowo 2:1 pada umur 30 HST sebanyak 25,21 batang, umur 60 HST sebanyak 27,11 batang dan umur 80 HST sebanyak 23,19 batang. Sedangkan pada sistem Tegel jumlah anakan produktif pada umur 30 HST sebanyak rata-rata 20,18 batang, umur 60 HST 23,19 batang dan umur 80 HST sebanyak 18,20 HST. Tinggi tanaman dan jumlah anakan terhadap perlakuan jajar legowo 2:1 dan Tegel dapat dilihat pada Tabel 1. 
Tabel 1

Rata-Rata Tinggi Tanaman dan Jumlah Anakan Perlakuan Sistem Legowo 2:1 dengan Sistem Tegel

\begin{tabular}{cccccccc}
\hline \multirow{2}{*}{ No } & \multicolumn{3}{c}{ Tinggi tanaman $(\mathrm{cm})$} & \multicolumn{3}{c}{ Jumlah anakan/rumpun } \\
& Perlakuan & \multicolumn{2}{c}{} & & & \\
\cline { 3 - 8 } & & 30 HST & 60 HST & 80 HST & 30 HST & 60 HST & 80 HST \\
\hline 1 & Legowo 2:1 & 72,21 & 108,10 & 110,10 & 25,21 & 27,11 & 23,19 \\
\hline 2 & Tegel & 70,11 & 105,22 & 108,11 & 20,18 & 23,19 & 18,20 \\
\hline
\end{tabular}

Keterangan :

HST : Hari Setelah Tanam

Pertumbuhan tanaman yang diukur dengan variabel tinggi tanaman, jumlah anakan pada sistem penanam jajar legowo 2:1 memberikan hasil yang lebih baik dari sistem tegel, hal ini disebabkan karena sistem jajar legowo merupakan suatu rekayasa teknologi untuk mendapatkan populasi tanaman lebih dari 160.000 per ha (sistem tegel); dimana pada sistem legowo 2;1 (25X12,5X50 cm) akan mendapatkan populasi tanam 213.300 rumpun (kementan, 2013). Disamping itu jajar legowo juga dapat meningkatkan kelancaran sirkulasi sinar matahari dan udara disekeliling yang berpengaruh terhadap potosintesis karena semua tanaman termasuk kategori tanaman pinggir. Tanaman pinggir akan menunjukan hasil yang lebih tinggi daripada tanaman yang ada dibagian dalam barisan, tanaman pinggir juga dapat menunjukan pertumbuhan yang lebih baik karena persaingan antar barisan dapat dikurangi (Balitbang Kementan, 2013; Hamdani dan Murtiani, 2014).

Variabel jumlah gabah yang terdiri dari indikator panjang malai (cm), gabah isi/malai, gabah hampa/malai dan produktivitas hasil sistem jajar legowo 2;1 memberikan hasil yang lebih efektif dari pada sistem tegel; dimana sistem tanam jajar legowo 2:1 mendapatkan panjang malai rata-rata $26,21 \mathrm{~cm}$, lebih panjang sebesar 8,66\% dibandingkan dengan sistem Tegel yang mencapai 24,12 cm dengan varietas yang sama yaitu varietas ciherang. Gabah isi/malai mencapai 120,21 bulir untuk penanaman sistem Jajar Legowo 2:1 lebih banyak sebesar 7,20\% jika dibandingkan dengan sistem Tegel yang mencapai 112,13 bulir. Gabah hampa permalai untuk perlakuan Legowo 2:1 mendapatkan 32,14 bulir lebih bernas sebesar 54,85\% jika dibandingkan dengan sistem Tagel yang mencapai 49,77 bulir. Rata-rata panjang malai, gabah isi dan gabah hampa pada perlakuan sistem Jajar Legowo 2:1 dengan Sistem Tegel dapat dilihat pada Tabel 2.

Tabel 2

Rata-Rata Panjang Malai, Gabah Isi, Gabah Hampa dan Produktivitas Hasil Perlakuan Sistem Legowo 2:1 dengan Sistem Tegel.

\begin{tabular}{|c|c|c|c|c|}
\hline \multirow{2}{*}{ NO } & \multirow{2}{*}{ Perlakuan } & \multicolumn{3}{|c|}{ Jumlah gabah (butir/malai) } \\
\hline & & $\begin{array}{l}\text { Panjang malai } \\
(\mathrm{cm})\end{array}$ & Gabah isi/malai & $\begin{array}{c}\text { Gabah hampa/ } \\
\text { malai }\end{array}$ \\
\hline 1 & Legowo 2:1 & 26.21 & 120.21 & 32.14 \\
\hline 2 & Tegel & 24.12 & 112.13 & 49.77 \\
\hline
\end{tabular}


Capaian hasi produktivitas hasil Gabah Kering Panen (GKP) untuk perlakuan sistem jajar legowo 2:1 produktivitas tertinggi dicapai pada interval produktivitas $>7,60-7,75$ ton /ha sebanyak 4 orang petani responden $(33,33 \%$ responden) termasuk kategori efektif, sedangkan terendah diperoleh pada interval produktivitas $>7,45-7,60$ dengan jumlah responden 1 orang petani $(8,32 \%)$ dengan kategori cukup efektif. Rata-rata produktivitas yang dicapai dengan perlakuan sistem Jajar Legowo 2:1 ini memperoleh 7,52 ton/ha.

Capaian hasil produktivitas Gabah Kering Panen untuk perlakuan sistem Tegel, produktivitas tertinggi diperoleh pada interval produksi $>6,04-6,22$ ton/ha sebanyak 6 orang petani $(40,00 \%)$ dengan kategori cukup efektif dan terendah $5,70-5,87$ ton/ha sebanyak 1 orang petani $(6,66 \%)$ dengan kategori tidak efektif. Rata-rata produktivitas yang diperoleh dengan sistem Tegel ini mencapai 6,20 ton/ha. Capaian hasil Produktivitas Hasil Gabah Kering Panen (GKP) dapat di lihat pada Tabel 3.

\section{Tabel 3}

Capaian hasil Produktivitas Hasil Gabah Kering Panen (GKP)

\begin{tabular}{|c|c|c|c|c|c|}
\hline No & Perlakuan & $\begin{array}{c}\text { Interval } \\
\text { Produktivitas } \\
\text { ton/Ha }\end{array}$ & $\begin{array}{c}\text { Jumlah } \\
\text { Responden } \\
\text { (orang) }\end{array}$ & $\begin{array}{c}\text { Persentase } \\
\text { Responden } \\
(\%)\end{array}$ & Kategori \\
\hline 1 & $\begin{array}{c}\text { Jajar } \\
\text { legowo } \\
2: 1\end{array}$ & $\begin{array}{c}7,15-7,30 \\
>7,30-7,45 \\
>7,45-7,60 \\
>7,60-7,75 \\
>7,75-7,90\end{array}$ & $\begin{array}{l}3 \\
2 \\
1 \\
4 \\
2\end{array}$ & $\begin{array}{c}25 \\
16,66 \\
8,33 \\
33,33 \\
16,66\end{array}$ & $\begin{array}{c}\text { Tidak efektif } \\
\text { Kurang efektif } \\
\text { Cukup efektif } \\
\text { Efektif } \\
\text { Sangat Efektif }\end{array}$ \\
\hline & Rata-rata & 7,52 & 12 & & \\
\hline 2 & $\begin{array}{c}\text { Sistem } \\
\text { Tegel }\end{array}$ & $\begin{array}{c}5,70-5,87 \\
>5,87-6,04 \\
>6,04-6,22 \\
>6,22-6,39 \\
>6,39-6,57\end{array}$ & $\begin{array}{l}1 \\
2 \\
6 \\
2 \\
4\end{array}$ & $\begin{array}{c}6,66 \\
13,33 \\
40,00 \\
13,33 \\
26,66\end{array}$ & $\begin{array}{c}\text { Tidak efektif } \\
\text { Kurang efektif } \\
\text { Cukup efektif } \\
\text { Efektif } \\
\text { Sangat Efektif }\end{array}$ \\
\hline & Rata-rata & 6,20 & 15 & & \\
\hline
\end{tabular}

Produktivitas rata-rata penanaman sistem jajar legowo 2:1 mendapatkan hasil 7.52 ton GKP (Gabah Kering Panen) lebih tinggi sebesar $1.320 \mathrm{~kg}$ (atau meningkat sebesar 21,29\%) jika dibandingkan dengan penanaman sistem tegel yang mencapai rata-rata produktivitas hasil sebesar 6.20 GKP.

Tingginya produktivitas jajar legowo 2:1 terhadap penanaman sistem tegel ini terjadi disebakan karena memiliki efek tanaman pinggir yang berpengaruh terhadap pertumbuhan tanaman yang lebih baik seperti panjang malai, pembernasan gabah isi/malai dan produktivitas. Dimana tanaman jajar legowo 2:1 dari ketiga variabel tersebut mendapatkan hasil yang lebih baik jika dibandingkan dengan sistem tegel; hal ini disebabkan faktor-faktor tumbuh yang tersedia seperti Co2, sinar matahari lebih baik untuk pembentukan hasil karena kompetisi yang terjadi lebih kecil dan secara fisiologi laju serapan hara oleh akar tanaman cenderung meningkat, yang menyebabkan produksi meningkat sehingga berpengaruh terhadap pendapatan petani (Hamdani dan Murtiani, 2014; Permata et al., 2017).

Pelaksaan penerapan sistem tanam jajar legowo 2:1 dilapangan, walaupun sudah terbukti dapat meningkatkan hasil pertanian, petani masih enggan menerapkannya hal ini disebabkan oleh beberapa hal 
seperti: (1) Mahalnya biaya menanam jika dibandingkan dengan sistem tegel (biaya menanam Jajar Legowo 2:1 per ha memerlukan biaya Rp 2.000.000,-, sedangkan untuk sistem tegel biasa Rp 1.600.000,/ha; (2) Kebanyakan petani penggarap; (3) Petani menjual padinya masih banyak ke penebas, sehingga tidak diketahui hasilnya yang riil. Hal ini sesuai dengan pendapatnya Adnyana, et.al., (2020) bahwa keberadaan tanaman pangan dan hortikultura cenderung mengalami permasalahan pada sistem agribisnisnya. Sistem agribisnis tersebut seperti pemasaran hasil yang masih rendah, hasil produki yang masih rendah yang berinplikasi terhadap pendapatan petani. Mengatasi permasalahan tersebut perlu dilakukan pendidikan informal petani berupa sekolah lapang untuk mengimbangi pendidikan formal petani, sehingga penerapan sistem agribisnis lebih terlaksana pada tingkat lapangan (Adnyana, et. al., 2017).

\section{PENUTUP}

\section{Simpulan}

Berdasarkan hasil penelitian dapat disimpulkan (1) Pertumbuhan tanaman padi seperti tinggi tanaman, jumlah anakan/rumpun, panjang malai, gabah isi/malai, gabah hampa/malai mendapatkan hasil lebih baik daripada sistem tegel, serta produktivitas penanaman sistem jajar legowo 2:1 mendapatkan hasil yang lebih efekktif jika dibandingkan menanam sistem tegel. Dimana sistem jajar legowo 2:1 mendapatkan hasil rata-rata 7.52 ton/ha GKP lebih tinggi sebesar 1,32 ton/ha jika dibandingkan dengan penanaman sistem tegel yang mendapatkan rata-rata hasil 6,20 ton/ha. (2) Permasalahan yang terjadi dilapangan dalam pelaksanaan sistem tanam jajar legowo 2:1 yaitu: mahalnya biaya penanaman, kebanyakan petani penggarap, petani kebanyakan menjual hasil panennya ke penebas.

\section{Saran}

Penanaman dengan sistem jajar legowo 2:1 terbukti lebih efektif didalam meningkatkan produksi, sehingga perlu dikembangkan lebih luas dalam penerapannya dilapangan, Perlu perhatian pemerintah didalam mensosialisasikannya kepada petani, diperlukan kombinasi penerapannya terhadap padi jenis hibrida, petani didalam memanen padi hendaknya dilakukan secara mandiri untuk mendapatkan pendapatan yang lebih banyak, Pengembangan kelompok menanam dan memanen perlu digalakan lagi, dan mengadakan sekolah lapang dengan sistem agribisnis.

\section{DAFTAR PUSTAKA}

Adnyana, N.S, Tenaya, M.N, dan Darmawan, D.P, 2017. Peranan Sistem Agribisnis Terhadap Keberhasilan Tumpangsari Cabai-Tembakau (Kasus Subak di Desa Sukawati, Kecamatan Sukawati, Kabupaten Gianyar). Journal Manajemen Agribisnis, Program Studi Magister Agribisnis, Program Pasca Sarjana, Universitas Udayana, 5(1):64-79.

Adnyana, N.S., Darmawan, D.P., Windia, W, and Suamba, K, 2020. Agribusiness Development Model For Strengthening The Chili-Tobacco Intercroping Farmer Group. International Journal Of Life Sciences. 4(1):26-36.

Atmosoeprapto, K. 2001. Produktivitas Aktualisasi Budaya Perusahan. Jakarta: PT Elex Media Komputindo Kelompok Gramedia.

Badan Penelitian dan Pengembangan Pertanian. 2013. Sistem Tanam Legowo. BB Padi Sukamandi. 
dwijenAGRO Vol. 10 No. 2, November 2020 ISSN : 1979-3901

Hamdani, K.K, dan Murtiani, S. 2014. Aplikasi Sistem Tanam Jajar Legowo untuk Meningkatkan Produktivitas Padi Sawah. Balai Pengkajian Teknologi Pertanian (BPTP) Jawa Barat. Journal Agros, 16 (2): 285-291.

Supari, D.H. 2002. Manajemen Produksi dan Operasi Agribisnis Hortikultura, Seri Praktek Ciputri Hijau. Jakarta: PT Elek Media Kompotindo.

Umar, H. 2005. Evaluasi Kinerja Perusahaan. Teknik Evaluasi Bisnis dan Kinerja Perusahaan Secara Komprehensip, Kuantitatif dan Modern. Cetakan Ketiga. Jakarta: PT Gramedia Pustaka Utama.

Permata, A.L, Widjaya, S, Soelaiman, A. 2017. Analisis Perbandingan Usahatani Padi Sistem Tanam Jajar Legowo dengan Sistem Tegel di Kecamatan Seputih Mataram di Kecamatan Lampung Tengah. Jurusan Agribisnis, Fakultas Pertanian, Universitas Lampung. Jounal JIIA, 5(1). 